\title{
HOMOSEXUALITY AND SELF-IMPOSED EXILE IN THE SONG OF EVERLASTING SORROW
}

Aiqing Wang / 王艾青 art ${ }^{\text {hin }}$ wan, University of Liverpool, Aiqing.Wang@liverpool.ac.uk

Original scientific paper

DOI: 10.31902/fll.36.2021.1

\begin{abstract}
In this paper, I hermeneutically scrutinise a 1995 award-winning masterpiece The Song of Everlasting Sorrow and investigate its homosexual motif that lacks sufficient critical analysis. The author Wang Anyi features emotional and erotic entanglements between an archetypal yet extraordinary Shanghai woman Wang Qiyao and an array of male characters. I propound that apart from the protagonist's unceasing melancholia, as illuminated by the title, the narrative also concerns lifelong dolorousness of two female supporting characters, viz. Wu Peizhen and Jiang Lili, both of whom establish bonds with Qiyao at puberty. I postulate that analogous to schoolgirls depicted by Ailing Zhang, Peizhen and Lili demonstrate same-sex adoration of Qiyao, yet disparate from spurious, proto- or quasi-homosexuality portrayed in Zhang's writing, their zealousness and loyalty to Qiyao are not fugacious. Moreover, Peizhen's perpetual animation is also inextricably intertwined with acrimony triggered by her failed pursuit of heterosexual romance with Qiyao's committed admirer, leading to Peizhen's unremitting self-mutilation and self-banishment.
\end{abstract}

Keywords: The Song of Everlasting Sorrow, Wang Anyi, homosexual intimacy, acrimony, self-banishment

\section{Introduction}

The 1995 novel 长恨歌 Changhen Ge 'The Song of Everlasting Sorrow' (henceforward Song) is the chef-d'oeuvre of an illustrious female novelist and screenwriter 王安忆 Wang Anyi (1954- ), a leading figure of Neorealism and post-Mao literary genres such as 伤痕文学 Shanghen Wenxue 'Scar Literature' and 寻根文学 Xungen Wenxue 'Root-Seeking Literature', who is celebrated for romantic self-expression, modernist style, critical realism and avant-garde narration (Feuerwerker 1998, Jing 2007, FitzGerald 2008, Zeng 2010, Castelli 2019). Wang endeavours to construct a language untainted by Maoist discourse and its ideological prescriptions and expounds psychological wounds and the devaluation of femininity during the Cultural Revolution (1966-1976) that leaves post-Mao women scarred for life (Wu 2013, Denton 2016). The 2017 
Newman Prize for Chinese Literature was bestowed upon Wang for her outstanding achievement and mega-writing of literature (Chiang and Rollins 2009, Newman Prize for Chinese Literature 2019); in the nomination statement, she is adulated as the most preponderant contemporary Chinese writer featured by mature and emotional insightfulness, who has illuminated the seismic transformations of China in the previous decades by means of innovative and consistent literary experiments, thereby elaborating Shanghai and even the whole country in literature (Dai and Feeley 2017). As a thought-provoking storyteller and a philosophical thinker, Wang's writing 'addresses not only China, Chinese life, and problems that Chinese people confront, but also grapples with universal modern conditions, taking long and broad views of human civilization and the evolution of people's living conditions. Shedding light on modern culture gone awry, she brings back the spectra of the past to weigh in on the present. She has invented ghosts of the past that come to haunt, derail, and critique modern life' (Wang 2018: 12).

Wang's writing bears similitude with that of 张爱玲 Zhang Ailing (aka Eileen Chang, 1920-1995), an iconic figure of urban modernist literature and public culture, who possessed splendid literary aptitude and literary prominence, as embodied by her sophisticated writing replete with stylistic devices and aestheticised details as well as an unparalleled mode of sensitivity and a multifaceted narrative configuration of temporality (Shen 2012, Wang 2012, Lee 2017, Weng 2018, Qu 2019). To be more specific, Wang demonstrates ambivalence towards Zhang's aesthetics of and penchant for detail: she lauds Zhang's devotion to details in life, whereas censures Zhang's aesthetic leap from the sensuous, viz. detail, to the nihilistic, viz. meaning; she deploys nostalgic details as signifying conduct to embrace idealism and reconstruct kaleidoscopic portraits of Shanghai in its previous incarnations, and strives to circumvent the dichotomy between detail and ideation (Xiao 2008). Moreover, notwithstanding the disparity that Zhang alternates between the real world and an illusory sphere in a nihilistic fashion yet Wang addresses real life and societal reality exclusively, both writers highlight nostalgia in old Shanghai by means of expatiating upon sumptuousness, cramped alleyway houses and the minutiae of everyday life, as well as typical indigenous women and their assiduousness, trivialities and travails (Gan 2004, Sun 2011, Bracken 2013, Bao 2017, Martin-Enebral 2017, Song 2017, Zhou 2018). Wang, therefore, is acclaimed as 'Eileen Chang's literary successor' of the 'Shanghai School' (Wang 1996, 2003, Xiao 2008, Basu and Guang 2010, Scheen 2015: 44). 
Song is construed as Wang's most well-established work, in that it attains critical accolades, commercial success and media adaptations, as well as the prestigious literary award Mao Dun Literature Prize in 2000 (Callil 2011, Lau 2011, Scheen 2015: 159, Jia 2014), and its publication marks new attention to female subjectivity (McDougall 2005) and nostalgia as a personalised remembrance emerged in the Chinese cultural scene of the mid-1990s (Jiang 2003, Wang 2016). Spanning four decades of eventfulness and political turmoil between 1945 and 1985, Song has its setting in evocative alleyways of pre-liberation and reformera Shanghai and concerns cathartic vicissitudes and dolorous denouements of the inconsequential petty bourgeoisie (Basu and Guang 2010, Hou 2014), so it is regarded as a post-revolutionary allegory of Shanghai in the $20^{\text {th }}$ century (Wang 1996, Zhang 2000, Xu 2011, Scheen 2015: 176) represented via male-female relationships (Lei 2013, Yin and Lin 2013). This embroidered narrative features the extraordinary life of the protagonist 王琦瑶 Wang Qiyao notwithstanding her identity as a quintessential ordinary city-dweller (Fong 2012, Lynton 2013): born into a working-class family in the crowded, labyrinthine alleyways, Wang Qiyao is crowned 'Miss Third Place' in the Shanghai Beauty Pageant, upon which she is reduced to a mistress of a powerful bureaucrat of the Nationalist regime; despite complex entanglements with several men at different stages, Wang Qiyao has no matrimonial relationship but an illegitimate daughter, and she is murdered by a thief for a box of gold bars left by the deceased bureaucrat (Long 2007, Wang 2016, Li 2017).

In this article, I investigate the everlasting sorrow encapsulated in Song, focusing on the unremitting melancholia of two supporting characters, i.e. 吴佩珍 Wu Peizhen and 蒋丽莉 Jiang Lili, which deserves more critical attention. Hermeneutic interpretation indicates that both characters exhibit homosexual adoration of the protagonist, and Lili's devotion is additionally intertwined with her heterosexual affection for the protagonist's faithful admirer.

\section{Title and sorrow}

The title of Song, viz. 长恨歌 Changhen Ge, is identical to that of a celebrated poem composed by a renowned realistic poet 白居易 Bai Juyi (aka Po Chü-I, 772-846 AD) of the Tang (618-907 AD) dynasty (Yang 1996, Shang 2011, Buswell and Lopez 2013, Luo 2018), a pioneer of an innovative genre dubbed as 新乐府 xin yuefu 'new music bureau/folksong' (DeBlasi 2002: 25, Chen 2015, Tan 2017), whose verse is characterised by a wide range of themes, styles and forms, as well as exquisite rhythm, plain language, deep nostalgia and elaborate 
depiction (Shields 2006, Chan 2011: 144, Zha 2015, Wang et al 2019). Bai's poetry can be categorised into four groups, concerning allegorical signifiers, leisure life, sentimental feelings and various metrical patterns (Fang 2010, Zhai 2019), and Changhen Ge is a paradigm of the third category, viz. 感伤诗 ganshang shi, in that this narrative chronicles the legendary love tragedy between Emperor Xuanzong (reign. 712-756 AD) and his royal consort, the notorious beauty Yang Guifei (aka Yang Yuhuan, 719-756 AD) (Mao 2016, Yu 2016, Sun and Gong 2017). This elaborate and aesthetic ballad is constituted of 120 lines in sevensyllable verse (Waley 2005: 44) and is replete with cultural images bearing implied connotations with and without figurative senses (Zhang 2002, Yang 2019). Moreover, there are sensual lines encapsulating obscenity that is fundamentally visual and hence invites voyeuristic imagination, thereby being perceived as the quintessence of erotic literature and inspiring following textual and visual works portraying Yang (Li 2008, Wang 2018). As an epitome of classical Chinese poetry that integrates aestheticism with sentimentalism, this poem manifests abstract aesthetic feeling with distinctive oriental colour in concrete imagery and narration, and thus substantially impinges upon East Asian poetry (Jiang 1999, Wang 2015, Zhang 2017).

Apart from the identical title, the correlation between Bai's poem and Wang's novel also lies in the latter's quotations of verses from the former, as well as analogous literary allusions pertaining to flora and fauna abounding in cultural connotations (Zeng 2013). More significantly, Wang's imitation and enrichment of the poem as an archetype can be embodied by her similar source of inspiration, political stance, depiction of male-female relationships, as well as unravelling of individuals' doomed victimisation in the event of destiny and time (Zhang 2000, Sun and Gong 2017). Furthermore, there is an intertextual correlation between Song and a 1688 drama 长生殿 Changshengdian 'Palace of Everlasting Life' composed by a Qing (1644-1912) playwright 洪昇 Hong Sheng (1645-1704) concerning this love tragedy of the Tang dynasty (Sun 2009, Stuckey 2010, Wang 2010).

As indicated by the title, Song concerns 'everlasting sorrow', which has been hermeneutically scrutinised from the perspective of the protagonist Wang Qiyao. Nonetheless, I postulate that apart from the perpetual melancholia and yearning of Qiyao, the narrative also alludes to that of two female supporting characters, i.e. Wu Peizhen and Jiang Lili.

In addition to a list of distinctive male characters romantically or erotically entangled with the heroine (Lee 2005, Liu and He 2010, Lei 
2013), Song entails female characters who have established multifaceted and fragile friendships with Qiyao since the bureaucrat's decease: Madame Yan, who perceives herself as 'a crane among chickens', demonstrates complex integration of conniving reverence and covetous disdain for Qiyao; the supercilious yet self-abased Zhang Yonghong extols Qiyao's fashion sense whereas endeavours to eclipse her (Wang 1996, Mao 2010, Dai 2014). At puberty in an all-girls school, however, Qiyao's female friends are exclusively Wu Peizhen and Jiang Lili, both of whom exhibit strong and sincere bonds with Qiyao prior to and after she becomes the renowned 沪上淑媛 Hushang Shuyuan 'Proper Young Lady of Shanghai' (trans. Berry and Chan 2008)' in 1945 Shanghai.

\section{3. 'Sisterly love' and homosexuality}

In this section, I explore the female-female friendship between the protagonist and the two supporting characters, and I propound that the 'sisterly love's is analogous to female same-sex bonds depicted by Zhang Ailing. The schoolgirl homosexual bond manifested by Jiang Lili is correlated with carnal intimacy, rather than just spiritual love. In terms of Wu Peizhen, her adoration of the protagonist is featured by unceasing melancholia and loyalty, as opposed to fugacious infatuations.

In Song, female-female friendship is referred to as 'sisterly love' (小 姊妹情谊 xiao zimei qingyi) that might be lifelong between girls and women in Shanghai. In Zhang's fiction composed in the US, such as the highly anticipated and contentious 相见欢 Xiangjianhuan 'Ecstasy of Encounters' and two posthumously-published narratives 小团圆 Xiao Tuanyuan 'Little Reunion' and 同学少年都不贱 Tongxue Shaonian Dou Bu Jian 'Schoolmates and Adolescents are All Meritorious' (trans. mine), there is an element concerning spurious, proto- or quasi-homosexuality between pubescent and mature females. In works appertaining to lesbian representation and sexuality, Zhang unravels fugacious impulse and precocious play of normal instinct among schoolgirls at the evolution of puberty in a form of sexual irritation fostered by physical intimacy (Chen 2004a, 2004b, Wang 2014).

In Song, Qiyao's girlhood friend Wu Peizhen has ardour for her, functioning as a paradigm of 'sisterly love'. Nonetheless, Peizhen's passion for Qiyao should not be analysed as pure friendship, but rather

\footnotetext{
${ }^{1}$ Unless specified otherwise, translations of all expressions and examples are cited from Berry and Chan (2008).
} 
female-female homosexuality, as illustrated in Example (1). Furthermore, I posit that parallel to Zhang's representation of schoolgirl homosexual romance as the incarnation of celebrity worship (Yan 2012), Peizhen's zealous fondness for Qiyao encapsulates her reverence and fantasy, as shown in Example (2). Nevertheless, given the fact that Qiyao also embraces Peizhen's worship and presumes herself to be an ideal idol, her failure to enter the film industry triggers her humiliation and reprehension against Peizhen, and hence the cessation of their friendship (Lei 2013, Dai 2014, Zheng 2019).

(1)

这晚上, 吴佩珍竟也做了个关于片厂的梦, 梦见水银灯下有个盛 装的女人，回眸一笑，竟是王琦瑶，不由感动得酸了。她对王琦 瑶的感情, 有点像一个少年对一个少女, 那种没有欲念的爱情, 为她做什么都肯的。

She dreamed of an elegantly dressed woman under the mercuryvapor lamps. When the woman turned to her and smiled, Wu Peizhen saw that she was none other than Wang Qiyao; she was so excited that she woke up. Her feelings for Wang Qiyao were a bit like the puppy love that a teenage boy feels for a girl for whom he is willing to go to the edge of the earth.

(Wang 1996. Trans. Berry and Chan 2008: 29)

(2)

由这谦虚出发，她就总无意地放大别人的优点，很忠实地崇拜， 随时准备奉献她的热诚。...吴佩珍的粗心其实只是不在乎，王 琦瑶的宽待她是心领的，于是加倍地要待她好，报恩似的。 In her modesty, she tended to exaggerate other people's strengths, place them on a pedestal, and offer them her devotion...Wu Peizhen's carelessness was the function of an uncalculating mind. She appreciated Wang Qiyao's magnanimity and tried even harder to please her as though repaying her kindness.

(Wang 1996. Trans. Berry and Chan 2008: 27)

In modern Chinese culture, female-female same-sex love is escalated by emotionally intense and physically intimate friendship and is inextricably intertwined with women's memory of adult femininity (Martin 2010: 12). That is to say, schoolgirl homosexual bonds are interconnected with carnal intimacy, as opposed to purely spiritual love. As mentioned previously, apart from Peizhen, same-sex closeness in Song can be attested from another girlhood friend, Jiang Lili. In Lili's initial encounter with Qiyao, physical contact accelerates her 'sisterly love' towards Qiyao, as shown in Example (3). Although I propound that 
Lili adopts a gender-separatist mode in which female femininity is a prerequisite shared by both partners (Rohy 2000: 4), rather than a gender-transitive framework entailing secondary genders of butches and femmes (Roof 1991: 5), Lili might subconsciously assume a gender role of a tomboy, triggered by Qiyao's inordinate feminine attraction while her own lack of it.

(3)

蒋丽莉还时不时将她的手紧握一下，似乎有什么你知我知的秘 密。这陡然而起的亲密, 是叫王琦瑶发窘, 可她面上并不流露, 也是知已的样子。

Meanwhile, Jiang Lili would give Wang Qiyao's hand a little squeeze from time to time, as if there were some secrets that only the two of them shared. But such forced intimacy only made Wang Qiyao ill at ease. However, no trace of uneasiness showed on her face and she continued to act as if she and Jiang Lili were the best of friends.

(Wang 1996. Trans. Berry and Chan 2008: 51)

It is noteworthy that the vast majority of female-female romantic/erotic practices are reduced to a temporary adolescent phase of spurious homosexuality, and only a trivial proportion of girls are congenitally predisposed to homosexuality in the presence of heteronormative sexual objects (Ellis 2001: 126, Ellis and Symonds 2008: 163). Nonetheless, I postulate that as manifested in the title, the 'sorrow' is 'everlasting' not only for the protagonist Qiyao, but also for her two female friends. Discrepant from Qiyao, whose sorrow is attributed to her emotional/erotic entanglements with various men as an ill-fated femme fatale, the 'everlasting sorrow' of Peizhen is triggered by her same-sex homosexual devotion to Qiyao. In stark contrast to spurious, proto- or quasi-homosexual relationships between pubescent girls in Zhang's fiction, the vast majority of which are fugacious, Peizhen's adoration of Qiyao is not an infatuation but characterised by unceasing melancholia and loyalty, as in Example (4), albeit Qiyao's irrational estrangement.

(4)

吴佩珍感觉到王琦瑶的回避, 不由黯然神伤。但她却并不丧失 信心, 她觉得无论过多少日子, 王琦瑶终究会回到她的身边。她 的友情化成虔诚的等待, 她甚至没有去交新的女朋友, 因不愿让 别人侵占王琦瑶的位置。

Sensing that she was being avoided, Wu Peizhen felt heartbroken, but she held on to the hope that Wang Qiyao would eventually come back to her. Her friendship changed into a kind of pious 
waiting; she did not even look for any new girlfriends, afraid that they might take Wang Qiyao's place.

(Wang 1996. Trans. Berry and Chan 2008: 38-39)

The temporariness of schoolgirl same-sex love indicated in Zhang's writing accords with the mass-cultural representation of temporary lesbian love between pubescent girls and youthful women in Chinese modernist literature during 1920 s and 1930s, which predominantly entails excruciating incursion imposed by socially mandated crossgender matrimonial relationships (Martin 2010: 12) and portrays idealised and failed romances featured by utopianism (Martin 2010: 51). In Song, however, Peizhen's homosexual adoration of Qiyao still exists after marriage: it can be seen from Example (5) that Qiyao has been serving as Peizhen's sole object of 'sisterly love', which cannot be circumnavigated or supressed by a heterosexual/matrimonial relationship.

(5)

她收起些局促, 身子坐正, 抬起脸, 对着王琦瑶说: 她这次冒昧地 上门, 是来向她告别的, 她本来不准 备打搅她, 可临到要走, 总觉 得不见她一面就走不了, 这一走, 不知什么时候才能见面, 王琦 瑶是她 最好的朋友, 也是唯一的朋友，她对于王琦瑶也许情形不 同, 可王琦瑶对于她确实如此, 上海这地方 叫她留恋的, 除了父 母家人, 就是王琦瑶了, 和王琦瑶做朋友的那一段, 是她最快乐, 最无忧虑的时光。

She recomposed herself and sat up to face Wang Qiyao, to tell her that she was sorry for the sudden visit but that she could not possibly leave without saying goodbye. Once she left, she said, she did not know when she would see her best friend, and her only friend, again. This might not be how Wang Qiyao viewed their friendship, she realized, but she herself had always done so. Apart from her own parents, Wang Qiyao would be the only person in Shanghai she was going to miss; their carefree time together had been the happiest in her life. Wu Peizhen was overstating the case, but it was true for her then and there.

(Wang 1996. Trans. Berry and Chan 2008: 135)

\section{Reprehension and self-imposed exile}

In this section, I focus on the character Jiang Lili and illustrate her reprehension and self-imposed exile triggered by her homosexual devotion to Qiyao and heterosexual adoration of Qiyao's admirer. Albeit merely assuming trivial roles in the narrative, such as sponsoring the 
protagonist's participation in the beauty pageant, Jiang Lili is represented as a multifaceted character with distinctive attributes and mindset (Berry 2017, Zheng 2019).

Parallel to Peizhen, Lili has been treating Qiyao as her only girlhood friend, and her loyalty and veneration for Qiyao does not vanish after the beauty pageant which marks the end of their puberty. Owing to her arrogant characteristic, mediocre appearance and thus lack of friends, Lili is eager to ingratiate herself with Qiyao. Additionally, her zealousness is enriched and fantasised by fictional works, which entertains herself and touches her own heart yet functions as a form of moral coercion for Qiyao, as in Example (6). Moreover, notwithstanding an affluent background, Lili is void of familial rapport and thus falls prey to loneliness and resorts to fiction prior to Qiyao's presence (Dai 2014, Zheng 2019), rendering her to deem Qiyao as the only beneficiary of her care and love (Example (7)). Analogous to schoolgirls embroidered in Zhang's narratives, Lili's admiration for Qiyao should also be perceived as fantasy projection, instead of her own homosexual recognition or identification.

(6)

这爱不仅是她自己的, 还加上小说里看来的, 王琦瑶真有些招架 不住了。

But this love issued not only from Jiang Lili. Much of it came from the novels she had read. Wang Qiyao could hardly bear it.

(Wang 1996. Trans. Berry and Chan 2008: 57)

(7)

上海小姐” 这称号对她无关紧要, 要紧的是王琦瑶。她想得王琦 瑶的欢心, 这心情是有些可怜见的。她对父母兄弟都是仇敌一 般, 唯独对个王琦瑶, 把心里的好兒底捧出来的, 好像要为她的 爱找个靶子似的。

The title of "Miss Shanghai" actually meant nothing to her-all that was important to Jiang Lili was Wang Qiyao. She wanted to win over Wang Qiyao's favor; it was, in fact, a little sad to see. Her parents and siblings she treated like enemies, reserving all her affection for Wang Qiyao, who seemed to be the longed-for target of her love.

(Wang 1996. Trans. Berry and Chan 2008: 57)

In addition to worshipping Qiyao in a quasi-homosexual manner, Lili exhibits complete adoration of an exemplary Shanghai gentleman $\mathrm{Mr}$ Cheng, which contributes to her lifelong sorrow and reprehension. $\mathrm{Mr}$ Cheng assumes a dual role as both a dedicated amateur photographer and aesthete who presents Qiyao's beauty to the old Shanghai, as well 
as a faithful admirer of Qiyao since her puberty, who adamantinely remains single until committing suicide after the advent of the Cultural Revolution in 1966 (Zhang 2000, Prose 2008, Martin-Enebral 2017). Nonetheless, Qiyao's aspirations lie in glory and upper-class extravagance (Lee 2005, Castelli 2019), so she declines yet exploits Mr Cheng's genuine love (Liu and He 2010, Fong 2012, Lei 2013). In a word, as illustrated in Example (8), Qiyao has always been treating Mr Cheng as a backup. Therefore, upon discovering Lili's deep affection for $\mathrm{Mr}$ Cheng, she ridicules Lili's reverie due to her self-confidence in retaining Mr Cheng's loyalty (Example (9)) and keeps deploying both of them.

(8)

倚靠的是哪一部分命运, 王琦瑶也不去细想, 想也想不过来。但 她可能这么以为, 退上一万步, 最后还有个程先生; 万事无成, 最 后也还有个程先生。总之, 程先生是个垫底的。

To what extent Wang Qiyao was willing to put her fate in his hands was something to which she gave little thought; she couldn't. Perhaps she was thinking: Even if I take ten thousand steps back, in the end I'll still have Mr. Cheng; even if everything comes to naught, when all is said and done, he will still be there. Mr. Cheng was her cushion.

(9)

(Wang 1996. Trans. Berry and Chan 2008: 85)

王琦瑶这么撮合蒋丽莉和程先生, 有一点为日后脱身考虑, 有一 点为照顾蒋家母女的心情，也有一点看笑话的。她再明白不过， 程先生的一颗心全在她的身上，这也是一点垫底的骄傲。看着 蒋丽莉 心甘情愿地碰壁, 虽也是不忍, 却还是解了一些心头委屈 似的。

By bringing together Jiang Lili and Mr. Cheng, Wang Qiyao was partially setting things up for her own retreat. It was also her way of looking out for Jiang Lili and her mother, as well as an opportunity to sit back and laugh at them. She knew better than anyone that Mr. Cheng had already invested his heart in her, which gave her self-esteem a padding she could always fall back on. Although it was painful to see Jiang Lili throwing herself against a brick wall, it was also a means for Wang Qiyao to vent some of her own pent-up resentment.

(Wang 1996. Trans. Berry and Chan 2008: 87)

In the narrative, there are paradigms illuminating Mr Cheng's wholehearted love for Qiyao and Lili's love for him. However, as is axiomatic for all three of them, $\mathrm{Mr}$ Cheng remains adamant and even 
intransigent in terms of his love for Qiyao, rendering Lili dolorous and despondent (Example (10)).

(10)

她痴痴地想了半天, 觉得了自己的可怜。从小到大, 都是别人为 她做的多，唯有两个人是反过来，是 她为他们做的多，这就是王 琦瑶和程先生, 偏偏是这两个人, 是最不顾忌她, 当她可有可无。 The very idea depressed her, and she spent the rest of the day feeling sorry for herself. Since she was a child, everyone had tried to please her; the only people she had ever tried to please were Wang Qiyao and Mr. Cheng. And in the eyes of these two people, she might as well have never existed.

(Wang 1996. Trans. Berry and Chan 2008: 120)

As a consequence of her ignored sincerity and failed pursuit of heterosexual romance, Lili harbours a grievance against Qiyao and $\mathrm{Mr}$ Cheng, thereby resolving to retaliate against them by means of punishing herself. Although born into a moneyed capitalist family with an extravagant lifestyle, Lili becomes an ardent communist in a Lenin suit, baggy khaki pants and shabby, dusty pigskin shoes. More significantly, apart from dishevelled appearance, Lili demonstrates recalcitrant defiance against her original social class and substitutes previous self-indulgence with self-discipline and political re-education: she ceases education to work as a factory labourer, marries a military representative she abominates and is keen to join the Communist Party. From Qiyao's perspective, Lili's radical transformation is self-fulfilling and self-deluding, as manifested in Example (11).

听她说着这些, 王琦瑶恍您看见了那个对月吟诗的蒋丽莉, 不过 那时吟的是风月，如今却是铁骨热血, 有点献祭的味道。两种都 带有夸张的戏剧的风格, 听起来总叫人不敢全信。但别人再是 怀疑, 蒋丽莉自己却是全心投入。听她说完, 王琦瑶便再无话可 说了。

Listening to her, Wang Qiyao could almost see the old Jiang Lili, that romantic poet she had known in her youth, reappear before her eyes. Times had changed, however, and Jiang Lili's odes to the wind and moon had been replaced by devoted words about steely determination and selfless sacrifice. Now, as then, however, the style smacked of theatrical exaggeration and was not entirely persuasive. Nonetheless, Jiang Lili's sincerity and dedication were not to be doubted. After listening to her lecture, Wang Qiyao was at an utter loss as to what else she could say. 
Furthermore, as can be seen from Example (12), Lili is fully aware of her anathema to the novel prevailing social and ideological norms, along with her work and marriage that are characterised by salient political connotations; she even disdains her three sons, in that as 'diminutive copies' of her husband, the three boys are 'rambunctious, foul-mouthed, disorderly, and dirty' and speak Mandarin 'with a thick rustic accent, reeked constantly of onions and garlic, and ha[ve] smelly feet' (Berry and Chan 2008: 264). However, Lili resolves to force herself to endure the abhorrence, so as to punish her previous animation for Qiyao and Mr Cheng. By means of torturing herself as self-imposed banishment, Lili surmises that she has managed to avenge on Qiyao and Mr Cheng with her 'whole life'. As a result, even if Lili is entrusted by Mr Cheng to attend Qiyao and her illegitimate newborn, she is still selfcontradictory between adoring Qiyao and $\mathrm{Mr}$ Cheng as well as resenting them along with the previous self inevitably intertwined with them (Example (13)).

这十多年来, 她过的是一种截然不同的生活。她以她历来的狂 热, 接受这生活里不堪承受的一面。从前放纵任性的冲动, 这时 全用在约束检讨自己。她的积极性令她左右上下的人都感到跟 不上。什么样的事情, 她都要做得过头。她自知是落后反动, 于 是做人行事就都反着她的心愿来, 越是不喜欢什么, 就越是要做 什么。比如和丈夫老张的婚姻, 再比如杨树浦的纱厂。她变得 越来越不像自己, 有点像演戏, 却是拿整个生活作剧情的。

For more than ten years now, Jiang Lili had been leading a radically different life. She had redirected her passion toward accepting everything that she had once found repugnant. Where she had been impulsive and self-indulgent, she was now self-critical and disciplined. Her ardor left everyone else straggling far behind. She took everything to the brink-and then some. To make up for her bad political background, she was determined always to go against what her heart truly desired-the more she abhorred something, the more she insisted on doing it. Marrying Old Zhang was one example, choosing to work at the cotton mill in Yangshupu another. As time went by, the old Jiang Lili grew increasingly distant; it was as if she was playacting, and her whole life was the play.

(Wang 1996. Trans. Berry and Chan 2008: 245) 
(13)

如今, 蒋丽莉每过十天半月就会来王琦瑶处坐一坐, 她对自己说 是为了受人之托。其实那只是一半。另一半是因为对旧时光 的怀恋, 这个怀恋甚至使她忽略了王琦瑶是她的 “情敌” 这一事 实。但 这是她不能正视的情感。她是要与旧时光一刀两断的 新人。

From this time on Jiang Lili began coming by to visit Wang Qiyao every two weeks or so. She told herself that she was merely holding true to the promise she had made, but that was only the half of it. The other thing that kept drawing her back was nostalgia; this nostalgia was so strong that it even allowed her to overlook the fact that Wang Qiyao was actually her rival in love. At the same time, however, she fancied herself as a product of the new society, someone who had made a clean break with the past.

(Wang 1996. Trans. Berry and Chan 2008: 263-264)

Although both Qiyao and Mr Cheng fully understand Lili's integrated love, acrimony and self-abasement, neither Qiyao or Lili unravels her ambivalence till Lili is diagnosed with fatal cancer. Being in her death throes, Lili eventually expresses her reprehension by means of chastising Qiyao and Mr Cheng for ruining her life, yet she still rejects Mr Cheng's visit as a gesture of atonement (Example (14)). In other words, Lili's paradoxical emotions and self-imposed exile last till her decease.

王琦瑶流着泪说: 蒋丽莉, 你多么不值得, 为了一个男人, 就不好 好做人了，你简直太俊了! 蒋丽莉 泪如泉涌地说道: 王琦瑶, 我 告诉你, 我这一辈子都是你们害的, 你们害死找了! 王琦瑶忍不 住抱 住她, 说: 蒋丽莉, 你以为我不知道? 你以为他不知道? 蒋 丽莉先是将她推开, 后又一把拉进怀里, 两人紧紧抱住, 哭得喘 不过气来。蒋丽莉说: 王琦瑶, 我真是太倒霉太倒霉了!

'Jiang Lili...' Wang Qiyao spoke through her tears. 'It's not worth it. Don't throw your life away for a man. How could you be so foolish?' Jiang Lili's tears were coming down in a steady stream. 'Well, let me tell you, Wang Qiyao. It's the two of you who have ruined my life, totally ruined it!' Wang Qiyao couldn't suppress the desire to console her; she reached out to hug her. 'Jiang Lili, do you think I don't know? Do you think he doesn't know?' At first Jiang Lili tried to push her away, but Wang Qiyao pulled her back into her arms and held her tight. They embraced and both were crying so hard that they could barely breathe. 'Wang Qiyao, I have had such wretched luck...such wretched luck!' Jiang Lili sobbed. 
(Wang 1996. Trans. Berry and Chan 2008: 279)

\section{Conclusion}

It is overwhelmingly acknowledged that the everlasting sorrow in the narrative, as indicated by the title, is correlated with the protagonist Qiyao. Nonetheless, the unremitting melancholia of Peizhen and Lili is prone to be neglected, so in this article, I explore these two multifaceted supporting characters, illustrating their complex homosexual bonds with the protagonist.

I propound that as Qiyao's girlhood friend, Peizhen exhibits 'sisterly love' and deep fondness for Qiyao in a homosexual fashion, which bears similitude to female characters in Zhang Ailing's writing appertaining to lesbian representation and female-female sexuality. Nevertheless, discrepant from schoolgirls depicted in Zhang Ailing's fiction, whose spurious, proto- or quasi-homosexual bonds are fugacious, Peizhen adores Qiyao even after she has established a heterosexual matrimonial relationship. After Qiyao vents reprehension against Peizhen by virtue of her failure to enter the film industry, she is worshipped by another schoolgirl, Lili, whose ardour, I argue, is intensified by emotional intensity, physical intimacy and fantasy projection. Nevertheless, I posit that Lili's devotion to Qiyao is entangled with her zealous affection for Qiyao's faithful admirer Mr Cheng, rendering Lili acrimonious for the rest of her life. Impinged upon by social transformations and haunted by agony, Lili resolves to go into self-imposed exile by means of defying against her original social class and family, converting to Communism, as well as substituting previous indulgence with political intransigence. That is to say, Lili's reprehension and self-imposed exile are caused by her homosexual devotion to Qiyao as well as an unsatisfied heterosexual desire.

\section{Works Cited}

Basu, Chitralekha and Yang Guang. 2010. An evergreen writer. China Daily. 19 July 2010. https://www.chinadaily.com.cn/life/201007/19/content_11590085.htm.

Bao, Junjie. 2017. 浅论女性与上海的关系一以张爱玲《倾城之恋》与王安 忆《长恨歌》为例 Qianxi nvxing yu shanghai de guanxi-Yi Zhang Ailing Qingcheng Zhilian yu Wang Anyi Changhenge weili [Discussion on the relation between women and Shanghai-Analysing Zhang Ailing's Qingcheng Zhilian and Wang Anyi's Changhenge]. Tangshan Literature 04: 134-135.

Berry, Michael. 2017. The Emergence of a Writer, the Evolution of a Literary Scene: In Conversation with Wang Anyi. Chinese Literature Today 6.2: 22-28. 
Berry, Michael and Susan Chan Egan. 2008. Trans. The Song of Everlasting Sorrow: A Novel of Shanghai. New York: Columbia University Press.

Bracken, Gregory. 2013. Cultural life: Film and literature. In The Shanghai Alleyway House: A Vanishing Urban Vernacular, 114-132. London and New York: Routledge.

Buswell, Robert E. Jr and Donald S. Lopez Jr. 2013. Bo Juyi. In The Princeton Dictionary of Buddhism. Princeton, NJ: Princeton University Press.

Callil, Carmen. 2011. Wang Anyi. The Guardian. 30 March 2011. https://www.theguardian.com/books/2011/mar/30/wang-anyi-profile.

Castelli, Alberto. 2019. Female Writing in Chinese Postmodern Literature: From Neorealism to Avant-garde. Interdisciplinary Literary Studies 21.4: 448475.

Chan, Hong-Mo. 2011. The Birth of China Seen Through Poetry. Singapore: World Scientific Publishing Company.

Chen, Sanping. 2015. Bai Juyi and Manna. Central Asiatic Journal. The Manchus and 'Tartar' Identity in the Chinese Empire 58.1-2: 17-25.

Chen, Zishan. 2004a. Introduction. In Tongxue Shaonian Dou Bu Jian, 1-8. Tianjin: Tianjin People's Publishing House.

Chen, Zishan. 2004b. Cong Xiao Tuanyuan dao Tongxue Shaonian Dou Bu Jian [From Little Reunion to Tongxue Shaonian Dou Bu Jian]. Lake Tai 03.

Chiang, Baochai and J. B. Rollins. 2009. The Song of Everlasting Sorrow: A Novel of Shanghai by Wang Anyi. World Literature Today 83.3: 64-65.

Dai, Jinhua and Jennifer Feeley. 2017. Writing as a Way of Life: Nomination of Wang Anyi for the Newman Prize for Chinese Literature. Chinese Literature Today 6.2: 8-9.

Dai, Wei. 2014. 解读《长恨歌》中不同形态的女性友谊 Jiedu Changhenge zhong butong xingtai de nvxing youyi [Analysing different types of femalefemale friendship in Changhenge]. Wenjiao Ziliao 06: 9-13.

DeBlasi, Anthony. 2002. Reform in the Balance: The Defense of Literary Culture in Mid-Tang China. Albany, NY: State University of New York Press.

Denton, Kirk A. 2016. Historical Overview. The Columbia Companion to Modern Chinese Literature, ed. Kirk Denton, 3-26. New York: Columbia University Press.

Ellis, Havelock. 2001. Studies in the Psychology of Sex: Sexual Inversion. Honolulu: University Press of the Pacific.

Ellis, Havelock and John Addington Symonds. 2008. Sexual Inversion: A Critical Edition, ed. Ivan Crozier. Houndmills, Basingstoke: Palgrave MacMillan.

Fang, Yuan. 2010. 白居易闲适诗研究 Bai Juyi xianshishi yanjiu [Analysis of Bai Juyi's leisure poems]. The Science Education Article Collects 03: 63-65.

Feuerwerker, Yi-tsi Mei. 1998. The Post-Modern 'Search for Roots' in Han Shaogong, Mo Yan, and Wang Anyi. In Ideology, Power, Text, SelfRepresentation and the Peasant 'Other' in Modern Chinese Literature, 188-238. Stanford, California: Stanford University Press.

FitzGerald, Carolyn. 2008. Imaginary Sites of Memory: Wang Zengqi and PostMao Reconstructions of the Native Land. Modern Chinese Literature and Culture 20.1: 72-128. 
Fong, lan Ho-yin. 2012. (Re-)Reading Shanghai's Futures in Ruins: Through the Legend of an (Extra-)Ordinary Woman in The Song of Everlasting Sorrow: A Novel of Shanghai. Culture Unbound 4: 229-248.

Gan, Xiaoyan. 2004. 宿命与守望一从《十八春》与《长恨歌》看张爱玲和 王安忆的生命审美意识 Suming yu shouwang-Cong Shibachun yu Changhenge kan Zhang Ailing he Wang Anyi de shengming shenmei yishi [Destiny and hope-Analysing the aesthetic awareness of Zhang Ailing and Wang Anyi from Shibachun and Changgenge]. Journal of Ningde Normal University 04: 47-49.

Hou, Jiali. 2014. 王安忆与张爱玲的都市小说创作比较一以《长恨歌》为例 Wang Anyi yu Zhang Ailing de dushi xiaoshuo chuangzuo bijiao-Yi Changhenge weili [Comparison of urban novels of Wang Anyi and Zhang Ailing--Using Changhenge as an example]. Beifang Wenxue: 21-22.

Jia, Mei. 2014. A slice of life close up. China Daily Africa. 28 February 2014. http://www.chinadaily.com.cn/a/201402/28/WS5a2a49e9a3101a51ddf9 03ac.html.

Jiang, Hong. 1999. 从《长恨歌》看白居易的叙情艺术 Cong Changhenge kan Bai Juyi de xuqing yishu [Analysing Bai Juyi's narrative art from Changhenge]. Journal of Anhui Agricultural 03: 114-115.

Jiang, Hong. 2003. The Personalization of Literature: Chinese Women's Writing in the 1990s. China Review 3.1. Special Issue: The Cultural Configuration of Literature and Film in 1990s China: A New Perspective: 5-27.

Jing, Kaixuan. 2007. Contemporary Chinese Fiction: Politics and Romance. Macalester International 18: 76-99.

Lau, Doretta. 2011. Chinese Writers Make Booker International Prize List. The Wall Street Journal. 08 April 2011. https://www.wsj.com/articles/BL-SJB7241.

Lee, Leo Ou-Fan. 2017. Eileen Chang in Hong Kong. In A new literary history of modern China, ed. Dewei Wang, 478-483. Cambridge, Massachusetts: The Belknap Press of Harvard University Press.

Lee, Vivian P. Y. 2005. The City as Seductress: Reimagining Shanghai in Contemporary Chinese Film and Fiction. Modern Chinese Literature and Culture 17.2: 133-166.

Lei, Jing. 2013. 长恨歌为何长恨 Changhenge weihe chang gen [The reasons of sorrow in Changhenge]. Wenjiao Ziliao 13: 5-10.

$\mathrm{Li}$, Juanmei. 2008. 从《长恨歌》看白居易的爱情观 Cong Changhenge kan Bai Juyi de aiqingguan [Analysing Bai Juyi's attitudes towards love from Changhenge]. Journal of Harbin Institute of Vocational Technology 05: 2223.

Li, Ruixue. 2017. 《长恨歌》弄堂文化与 “王琦瑶” 的悲剧命运 Changhenge nontang wenhua yu Wang Qiyao de beiju mingyun [The nontang culture in Changhenge and the tragic fate of Wang Qiyao]. Youth Literator: 40-41.

Liu, Fangchi and Limin He. 2010. 对男权社会的无奈认同一王安忆《长恨歌》 中男性形象解读 Dui nanquan shehui de wunai renting-Wang Anyi Changhenge zhong nanxing xingxiang jiedu [Recognition of the patriotic 
society-Analysing male characters in Wang Anyi's Changhenge]. Shidai Wenxue: 118-120.

Long, Ying. 2007. 论王安忆小说《长恨歌》中女性意识的缺失 Lun Wang Anyi xiaoshuo Changgenge zhong nvxing yishi de queshi [An analysis of the lack of feminist thinking in Wang Anyi's Changhenge]. Times Figure 12: 8889.

Luo, Manling. 2018. Tang Civil Service Examinations. In How to Read Chinese Poetry in Context: Poetic Culture from Antiquity Through the Tang, ed. Zong-qi Cai, 173-184. New York: Columbia University Press.

Lynton, Jordan. 2013. An intersectional comparison of female agency in Toni Morrison's Sula and Wang Anyi's Song of Everlasting Sorrow. HIM 19902015. 1428.

Mao, Sanyan. 2010. 论《长恨歌》中的女性关系 Lun Changhenge zhongde nvxing guanxi [Female-female relationships in Changhenge]. Journal of Hubei University of Education 27.12: 18-20.

Mao, Xiaofen. 2016. 解读《长恨歌》白居易的 “符离之恋” Jiedu Changhenge Bai Juyi de fuli zhilian [An analysis of love in Bai Juyi's Changhenge]. Language Planning 04: 49-50.

Martin, Fran. 2010. Backward Glances: Contemporary Chinese Cultures and the Female Homoerotic Imaginary. Durham and London: Duke University Press.

Martin-Enebral, Elena. 2017. From Nostalgia to Reflection: An Exploration of The Song of Everlasting Sorrow by Wang Anyi. Chinese Literature Today 6.2: 43-51.

McDougall, Bonnie S. 2005. Discourse on Privacy by Women Writers in Late Twentieth-Century China. China Information 19.1: 97-119.

Newman Prize for Chinese Literature. 2019. 2017 Winner Wang Anyi. 4 October $2019 . \quad$ https://www.newman-prize-for-chineseliterature.oucreate.com/winners/2017-wang-anyi/.

Prose, Francine. 2008. Miss Shanghai. The New York Times. 04 May 2008. https://www.nytimes.com/2008/05/04/books/review/Prose-t.html.

Qu, Lina. 2019. Writing, Rewriting, and Miswriting: Eileen Chang's Late Style Against the Grain. CLCWeb: Comparative Literature and Culture 21.6. https://doi.org/10.7771/1481-4374.3305.

Rohy, Valerie. 2000. Impossible Women: Lesbian Figures \& American Literature. Ithaca and London: Cornell University Press.

Roof, Judith. 1991. A Lure of Knowledge: Lesbian Sexuality and Theory. New York: Columbia University Press.

Scheen, Lena. 2015. Shanghai Literary Imaginings: A City in Transformation. Amsterdam: Amsterdam University Press.

Shang, Yongliang. 2011. A controversial poet, a forgotten dynasty: Jin dynasty poets' reception of Bai Juyi and its historical significance Shang. Frontiers of Literary Studies in China 5: 25-47.

Shen, Shuang. 2012. Ends of Betrayal: Diaspora and Historical Representation in the Late Works of Zhang Ailing. Modern Chinese Literature and Culture 24.1: 112-148. 
Shields, Anna M. 2006. Remembering When: The Uses of Nostalgia in the Poetry of Bai Juyi and Yuan Zhen. Harvard Journal of Asiatic Studies 66.2: 321361.

Song, Dan. 2017. 从《传奇》到《长恨歌》一简析张爱玲、王安忆笔下上海 女性的形象特点 Cong Chuanqi dao Changhenge-Jianxi Zhang Ailing Wang Anyi bixia Shanghai nvxing de xingxiang tedian [From Chuanqi to Changhenge-Analysing the characteristics of women in Shanghai depicted by Zhang Ailing and Wang Anyi]. Beifang Wenxue 17: 282.

Stuckey, Andrew G. 2010. Back to the Future: Temporality and Cliché in Wang Anyi's Song of Everlasting Sorrow. In Old Stories Retold: Narrative and Vanishing Pasts in Modern China. Lanham: Lexington Books.

Sun, Guiping. 2009. 论《长生殿》的情爱主题与写情艺术 Lun Changshengdian de qingai zhuti yu xieqing yishu [Love theme and love description in The Palace of Eternal Youth]. Journal of Wenzhou University 22.2: 81-86.

Sun, Shu. 2011. 《长恨歌》与《传奇》一王安忆与张爱玲笔下的上海 Changhenge yu Chuanqi-Wang Anyi yu Zhang Ailing bixia de Shanghai [Changhenge and Chuanqi-The Shanghai depicted by Wang Anyi and Zhang Ailing]. Journal of Hubei Correspondence University 24.9: 145-146.

Sun, Yuanyuan and Fang Gong. 2017. 论王安忆《长恨歌》对白居易《长恨 歌》的继承和发展 Lun Wang Anyi Changhenge dui Bai Juyi Changhenge de jicheng he fazhan [The imitation and development of Wang Anyi's Changhenge for Bai Juyi's Changhenge]. Youth Literator: 25-27.

Tan, Mei Ah. 2017. New Music Bureau Poetry as Memorial: The True Significance of Yuan Zhen's 'Shangyang Baifa Ren'. Tang Studies 35.1: 87108.

Waley, Arthur. 2005. The Life and Times of Po Chü-I 772-846 AD. London and New York: Routledge.

Wang, Anyi. 1996. 长恨歌 Changhen Ge. Beijing: China Writers Publishing House.

Wang, Ao. 2018. Poetry and Literati Friendship: Bai Juyi and Yuan Zhen. In How to Read Chinese Poetry in Context: Poetic Culture from Antiquity Through the Tang, ed. Zong-qi Cai, 248-260. New York: Columbia University Press.

Wang, Bailing. 2014. 百合花开一论张爱玲 20 世纪 50 年代以后的女同性恋 文本叙事 Baihehua kai-Lun Zhang Ailing ershi shiji wushi niandai yihou de nvtongxinglian wenben xushi [Lily flower in blossom - Lesbian novel of Zhang Ailing after the 1950s]. Journal of Jiaxing University 26.5: 67-70.

Wang, Ban. 2018. Wang Anyi: The Storyteller as Thinker. Chinese Literature Today 6.2: 12-13.

Wang, David Der-wei. 1996. 海派文学又见传人 Haipai wenxue youjian chuanren [A New Successor of the Shanghai School]. Reading 06: 37-44.

Wang, David Der-wei. 2003. 半生缘, 一世情一张爱玲与海派小说传统 Bansheng yuan, yishi qing: Zhang Ailing yu haipai xiaoshuo chuantong [Eighteen springs, a century of love: Zhang Ailing and Shanghai-school fictional tradition]. In 回望张爱玲: 华丽影沉 Hui wang Zhang Ailing: Huali 
ying chen [Zhang Ailing Retrospective: The Sumptuous Sinking Shadow], ed. Hongda Jin. Beijing: Wenhua Yishu Chubanshe.

Wang, David Der-wei. 2012. Madame White. The Book of Change, and Eileen Chang: On a Poetics of Involution and Derivation. In Eileen Chang: Romancing Languages, Cultures and Genres, ed. Kam Louie, 215-242. Hong Kong: Hong Kong University Press.

Wang, Haihua. 2015. 浅谈白居易《长恨歌》的价值 Qiantan Bai Juyi Changghenge de jiazhi [The value of Bai Juyi's Changhenge]. New Courses' Study 06: 167.

Wang, Jian. 2010. 从《长生殿》对天宝故事的取舍看其主题思想 Cong Changshengdian dui tianbao gushi de qushe kan zhuti sixiang [Theme of the Eternal Youth Palace based on the historical events of Tianbao years in the Tang dynasty]. Journal of Shiyan Technical Institute 23.5: 67-70.

Wang, Lingzhen. 2016. Wang Anyi. The Columbia Companion to Modern Chinese Literature, ed. Kirk Denton, 371-378. New York: Columbia University Press.

Wang, Yimei, Xiaolan Tang, Kongfei Zhou, Hexuan Wang and Qing Chen. 2019. 文人造园家白居易的月意象探析 Wenren zao jiayuan Bai Juyi de yueyixiang tanxi [An analysis of the moon imagery in literati landscape gardener Bai Juyi]. Landscape Art 02: 46-50.

Weng, Leihua. 2018. Modernity in a Wartime Tramcar. The Comparatist 42: 286-303.

Wu, Hui. 2013. Post-Mao Chinese Literary Women's Rhetoric Revisited: A Case for an Enlightened Feminist Rhetorical Theory. College English 72.4: 406423.

Xiao, Jiwei. 2008. Can She Say No to Zhang Ailing? Detail, idealism and woman in Wang Anyi's fiction. Journal of Contemporary China 17.56: 513-528.

$\mathrm{Xu}$, Lanjun. 2011. Constructing girlhood: Female adolescence, depression and the making of a female tradition in modern Chinese literature. Frontiers of Literary Studies in China 5: 321-349.

Yan, Zeya. 2012. 张爱玲一题三写一析《留情》 《相见欢》《同学少年都不 贱》Zhang Ailing yiti sanxie-xi 'Liu Qing', 'Xiangjian Huan', 'Tongxue Shaonian Dou Bu Jian' [Zhang Ailing's one topic and three interpretations-analysing Liu qing, Xiangjian Huan and Tongxue Shaonian Dou Bu Jian]. Ink 111: 88-95.

Yang, Xiaoshan. 1996. Having It Both Ways: Manors and Manners in Bai Juyi's Poetry. Harvard Journal of Asiatic Studies 56.1: 123-149.

Yang, Yiying. 2019. On Translation of Cultural Images in Chang Hen Ge from the Perspective of Reception Theory. Chinese Journal of Applied Linguistics 42.4: 527-541.

Yin, Wujing and Danya Lin. 2013. 不同历史想象中的女性形象一论《长恨歌 》与《白鹿原》叙事中的两性差异 Butong lishi xiangxiangzhongde nvxing xingxiang - Lun Changhenge yu Bailuyuan xushizhongde liangxing chayi [different feminine images in historical imagination: Considering gender differences in the narratives of The Song of Everlasting Sorrow and 
White Deer Prairie]. Journal of China Women's University 01: 78-82.

Yu, Liyuan. 2016. 白居易《长恨歌》赏析 Bai Juyi Changhenge shangxi [Analysis of Bai Juyi's Changhenge]. Modern Chinese 02: 15-16.

Zeng, Hong. 2010. Photography in Wang's Chang Hen Ge (The Song of Everlasting Sorrow). CLCWeb: Comparative Literature and Culture 12.3. https://doi.org/10.7771/1481-4374.1462.

Zeng, Yan. 2013. 白居易与王安忆《长恨歌》Bai Juyi yu Wang Anyi Changhenge [Relationship between Bai Juyi and Wang Anyi's Everlasting Regret]. Journal of Chongqing Jiaotong University 13.2: 82-84.

Zha, Zhengqian. 2015. 论自注所示白居易诗歌创作的若干特征与意义 Lun zizhu suoshi Bai Juyi shige chuangzuo de ruogan tezheng yu yiyi [Analysing the characteristics and meanings of Bai Juyi's poetry from his own notes]. Literary Heritage 02: 85-93.

Zhai, Yujia. 2019. 白居易“闲适诗”创作研究 Bai Juyi xianshishi chuangzuo yanjiu [Analysis of Bai Juyi's creation of poems on leisure life]. Youth Literator 17.

Zhang, Jun. 2002. 长恨歌哭为湘灵一白居易《长恨歌》抒情客体论 Changhenge ku wei xiangling-Bai Juyi Changhenge shuqing keti lun [Song of Lament for Xiang Ling-On the real object of Bai Juyi's lyrical 'Song of Lament']. Journal of Nanchang University 33.2: 103-105.

Zhang, Xudong. 2000. Shanghai Nostalgia: Postrevolutionary Allegories in Wang Anyi's Literary Production in the 1990s. Positions: East Asia Cultures Critique 8.2: 349-387.

Zhang, Yehong. 2017. Interdisciplinary Study on Cross-Cultural Poetry Reading. Comparative Literature Studies 54.4: 850-868.

Zheng, Zhi. 2019. 解读《长恨歌》中的“姐妹情谊” Jiedu Changhenge zhongde jiemei qingyi [Analysing the 'sisterhood' in Changhenge]. Youth Literator 18.

Zhou, Shiyu. 2018. A Tale of Two Cities: Woman and City in 'The Age of Innocence' and 'The Song of Everlasting Sorrow'. Advances in Social Science, Education and Humanities Research 181: 691-694. 


\section{《长恨歌》中的同性情愫与自我放逐}

本文旨在探讨王安忆发表于 1995 年的长篇小说《长恨歌》。作者描绘了 一位典型的上海女性王琦瑶与不同男性角色之间的爱恨纠葛，而书中的同 性恋情愫却少有研究。如题目所示, 《长恨歌》不仅揭示了主人公王琦瑶 的凄惨命运, 还暗示了其他两位女性角色的毕生痛苦, 即王琦瑶少女时期的 亲密女伴吴佩珍和蒋丽莉。与张爱玲笔下的女学生相似, 吴佩珍和蒋丽莉 对王琦瑶展现出同性间的爱恋。而与张爱玲笔下短暂的迷恋不同，两位女 性配角对主角的情感更为采热而忠诚。此外，蒋丽莉对王琦瑶的毕生追求 者爱而不得, 这份失败的异性恋情进一步加剧了她的悲剧色彩, 并最终导致 了她的自我毁灭与放逐。

关键词

长恨歌》，王安忆，哀恸，同性情感，自我放逐 